\title{
Primordialism and Voting Behavior of Malay Ethnic during the 2005-2015 Riau Islands Governor Election
}

\author{
Kustiawan 1,* (D) and Rumzi Samin 2 (D) \\ ${ }^{1}$ Department of Government Science, Faculty of Social and Political Sciences, \\ Universitas Maritim Raja Ali Haji, 29100, Tanjung Pinang, Riau Islands, Indonesia \\ 2 Department of State Administration, Faculty of Social and Political Sciences, \\ Universitas Maritim Raja Ali Haji, 29100, Tanjung Pinang, Riau Islands, Indonesia \\ *Corresponding Author: kustiawan@umrah.ac.id
}

\section{ARTICLE INFO}

\section{Publication Info: \\ Research Article}

How to cite:

Kustiawan, K., E Samin, R. (2020). Primordialism and Voting Behavior of Malay Ethnic during the 2005-2015 Riau Islands Governor Election. Society, 8(2), 372-389.

DOI: $10.33019 /$ society.v8i2.207

Copyright (C) 2020. Owned by Author(s), published by Society

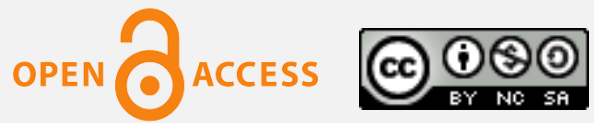

This is an open-access article.

\section{License: Attribution- \\ NonCommercial-ShareAlike (CC BY-NC-SA)}

Received: July 13, 2020;

Accepted: August 22, 2020;

Published: August 31, 2020;

\begin{abstract}
This research aims to examine primordialism and voting behavior of Malay ethnic during the 2005-2015 Riau Islands governor election (Pemilihan Gubernur or Pilgub). The political phenomenon in Riau Islands seems to be different from other areas where other Malays dominate since non-Malay ethnic candidates won the governor election. This research used a qualitative method with a descriptive technique. The data were collected using in-depth interviews and direct observation. Informants were selected using a purposive sampling technique. The result found that people of Malay ethnic are open-minded. The candidates elected also can prove qualified personal and successfully leading the Malay ethnic people in moving ahead. Non-Malay ethnic won the Riau Islands (known as Kepri (Kepulauan Riau)) governor election determined by 1) The political identity of Malay ethnic people is open-minded, coexisting Islamic identity, speaking Malay language, practicing Malay culture, and committing to build and develop Malay ethnic people, so the candidates identified as part of Malay ethnic people and considered by the Malay ethnic people as a candidate for leader of the Malay people in a broadening sense; 2) the figure of candidates can socialize with people of Malay ethnic; 3) other minority ethnics and political parties supported the candidates. Native Malay candidates were failed due to the lack of contribution to the people of Malay ethnic in particular and the Riau Islands in general.
\end{abstract}

Keywords: Malay; Governor; Pilgub; Political Identity; Primordialism; Riau Islands; Voting Behavior

Copyright (C 2020. Owned by Author(s), published by Society. This is an open-access article under the CC-BY-NC-SA license. 


\section{Primordialism and Voting Behavior of Malay Ethnic during the 2005-2015 \\ Riau Islands Governor Election}

\section{Introduction}

Regional leader election is one of the important events in political activities to elect the regional leader and vice regional leader. The regional leader and vice regional leader include the governor and vice governor, regent and vice-regent, the mayor and vice mayor. Discussions on the governor election (governor and vice governor) are increasingly significant in the realm of local politics, especially if the discussion is linked to the expansion of the New Autonomous Region in the implementation of a system for the direct election of local leaders. In research from Muhtadi (2018), stated that several significant factors in the election include political identity consisting of religion and ethnicity. As a result, the analysis of variables used in voting behavior research is more on the socio-religious, socio-cultural, or socio-economic approaches (Gaffar, 1992; King, 2003; Ananta et al., 2004) as cited in Haryanto (2014). On the other hand, this research illustrates that voter orientation towards politics is influenced by the personal quality of the candidate that has been built for a long time and has strong ties to the community so that the popularity of the candidate is based on the policy agenda. The focus of this research is on how primordialism and the voter behavior of Malay ethnic during the 2005-2015 Riau Islands governor election.

Since 2005, the direct regional leader election was conducted in all regions of Indonesia. The first regional leader election for Regent and Vice-Regent was conducted in June 2005, in Kutai Kartanegara Regency, East Kalimantan. Previously, regional leaders were elected by the Regional People's Representative Assembly (Dewan Perwakilan Rakyat Daerah or DPRD). However, this change strengthened the spirit of primordialism. Not surprisingly when the issue of ethnicity in Indonesia today is very dominant in the regional leader election. The ethnic identity and image of the candidate for regional leaders to be elected constitute political identity, which for voters is an important consideration in political behavior. According to Nicholson (2008), political identity is a political movement that arises and develops from the situation of minority and differentiated groups by the majority in a community of a country. The potential for diversity which is the power to carry out political movements raises communal awareness so that the differences in identity rise to communal awareness. As a communal force, cultural identity in this case is quite effective in binding and integrating oneself in a community construction that behaves with values.

Overseas, political identity dominant in Arab (Ben-Bassat \& Dahan, 2010), and took place in India (Kaul, 2013). The phenomenon that can be considered as a paradox in democracy has manifested itself in the democratic process in several regions in the current regional autonomy era. Ethnicity and religion as one of the social categories then develop into the most important parts of political identity, and even these social symbols and categories often become the basis of legitimacy in political competition in the regions. Then, it's resulted in the term ethnic politics (Kristianus, 2016, p. 88). Ethnic identity in political contestation of regional leader election is used in three ways, 1) in mobilizing tribal symbols; 2) be the consideration of voters, and 3) in the selection and strategy of candidates such as Sons of the soil (Aspinall, 2011). Local politics in West Kalimantan is heavily laden with ethnic political identity. The Dayak and ethnic Malays compete for political power in the regional leader election. Competition occurs since the ruling ethnic elite always exercise ethnic hegemony over other ethnicities. Of the seven districts in West Kalimantan that held the regional leader election, it is very clear that they are ethnically oriented to win votes (Kristianus: 2016, p. 87). In the context of the regional leader election, identification of ethnic identities is important to gain political support. The identification of ethnic identities is more widely applied in multi-ethnic societies (Lampe, 2010, p. 300).

Copyright (C) 2020. Owned by Author(s), published by Society. This is an open-access article under the CC-BY-NC-SA license. 
In several regions in Indonesia, since the reform era, ethnic politics has been dominant in regional leader election. Ontological and sociological facts and realities state that people's sovereignty in the direct regional leader election has strengthened ethnic/tribal domination in a multi-ethnic society displayed in the form of political identity. In research from Hemay \& Munandar (2016) stated that ethnic politics strengthened in the 2010 Bengkulu regional leader election. According to Nasution (2014), the dominance of ethnic politics has also occurred in Medan. In research from Aspinall (2011), also stated that the dominance of ethnicity politics with ethnic identity in the regional leader election in Indonesia. In research from Buchari (2014) stated that ethnic Dayak politics in the 2007 West Kalimantan regional leader election have strengthened. This is in line with the research from Trihartono \& Patriadi (2016), where ethnic and sectarian politics in the 2014 elections in Indonesia strengthened. Divisions in the form of ethnicities and political flow cannot be abandoned in the Indonesian elections. Even political flow may be one dimension of the endogeneity of religiopolitical identities. The revival of ethnic identity in Indonesia's regions has been rolling since the holding of direct general elections in 2004. Political Identity has occurred due to religious, ethnic, regional autonomy and administrative decentralization conflicts in the regions as studied by Schulte Nordholt, namely ethnic conflicts, regional autonomy, administrative decentralization outside Java Island is a political identity that exists. Religious and ethnic political identities are a repertoire for political interests, such as in Riau and Bali (Nordholt, 2008).

The results of previous studies above show that political identity occurs in local politics even it has become stronger in the regional leader election. In this research, the political phenomenon in Riau Islands seems to be different from other areas where other Malays dominate since non-Malay ethnic candidates won the regional leader election. Malay political identity does not occur for local politics in the Riau Islands regional leader election.

Riau Islands Province with an area of $425,214,676 \mathrm{~km}^{2}$ with 95 percent of its territory consisting of oceans and has 2,408 islands stretching from the Malacca Strait to the South China Sea and directly bordering several neighboring countries consisting of Singapore, Malaysia, Cambodia, and Vietnam is one of the maritime provinces. Riau Islands has a population of 1,864,142 (2015) inhabited by Malay $29.97 \%$, Javanese $24.97 \%$, Batak $12.48 \%$, Minangkabau 9.71\%, Chinese $7.70 \%$, Sundanese 2.96\%, Bugis 2.22\%, NTT Tribe $2.22 \%$, South Sumatra Tribe $1.97 \%$, Banjar $0.70 \%$, and other tribes $5.10 \%$. The Malay ethnicity is the dominant ethnicity in the Riau Islands Province (Badan Pusat Statistik Provinsi Kepulauan Riau, 2015).

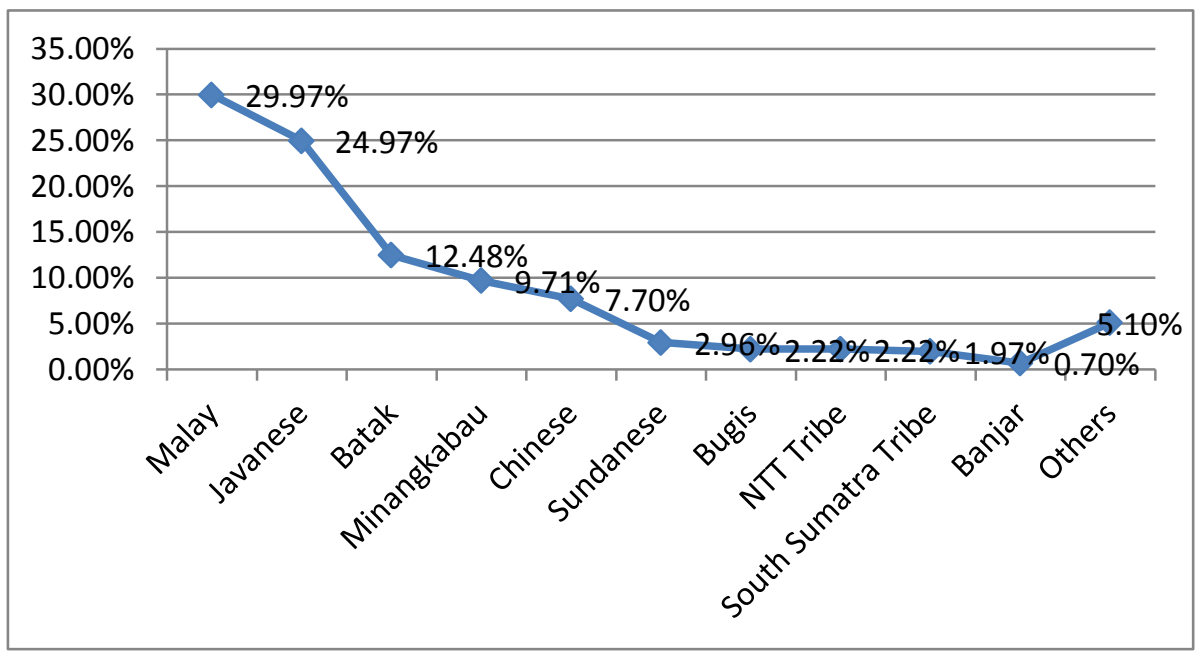

Figure 1. The Percentage of Ethnics in the Riau Islands Source: Badan Pusat Statistik Provinsi Kepulauan Riau (2015)

Copyright (C 2020. Owned by Author(s), published by Society. This is an open-access article under the CC-BY-NC-SA license. 


\section{Primordialism and Voting Behavior of Malay Ethnic during the 2005-2015 \\ Riau Islands Governor Election}

Based on Figure 1 above, 29.97\% of Malay ethnic groups are Malay people who are considered genealogically (descendants of Malay). However, the definition of Malay people in this research is that Malays is associated with Islam, language, and customs, which are then called indigenous voters so that the work of Malay political identity which is identical to Islam, $78.15 \%$ of Muslim voters in Riau Islands are called native voters as indigenous Malay identity. Based on the distribution of the population according to regencies/municipalities and the religion adhered to in the Riau Islands in 2019, it can be proved that the Muslim population (Malay identity) in each regency/municipality in Riau Islands is more than $70 \%$ Muslim who identify themselves as Malay (Table 1).

Table 1. Population Percentage by Regency/Municipality and Religion in Riau Islands

\begin{tabular}{|c|c|c|c|c|c|c|}
\hline \multirow{2}{*}{ Regency/Municipality } & \multicolumn{6}{|c|}{ Religion } \\
\hline & Islam & Protestant & Catholic & Hindu & Buddha & Others \\
\hline \multicolumn{7}{|l|}{ Regency } \\
\hline 1. Karimun & 85.06 & 3.64 & 0.99 & 0.01 & 9.95 & 0.36 \\
\hline 2. Bintan & 87.58 & 5.00 & 2.20 & 0.08 & 4.81 & 0.33 \\
\hline 3. Natuna & 96.97 & 1.39 & 0.35 & - & 1.13 & 0.15 \\
\hline 4. Lingga & 91.63 & 1.72 & 1.10 & - & 5.49 & 0.06 \\
\hline 5. Anambas Islands & 93.26 & 2.06 & 2.29 & - & 2.38 & 0.01 \\
\hline \multicolumn{7}{|l|}{ Municipality } \\
\hline 1. Batam & 71.73 & 17.94 & 3.28 & 0.06 & 6.86 & 0.12 \\
\hline 2. Tanjungpinang & 79.58 & 6.32 & 1.35 & 0.02 & 12.49 & 0.25 \\
\hline Riau Islands & 78.15 & 11.89 & 2.43 & 0.05 & 7.31 & 0.18 \\
\hline
\end{tabular}

Source: Dinas Pemberdayaan Masyarakat dan Desa, Kependudukan dan Pencatatan Sipil

Provinsi Kepulauan Riau (2019)

Based on direct observations, the governor elections in the Riau Islands during three periods of 2005, 2010, and 2015 were always won by non-Malay ethnic candidates. Despite being an ethnic minority, the non-Malay candidate pair, Ismeth Abdullah and H. Muhammad Sani won the election for governor and vice governor of the Riau Islands in 2005 (Detiknews.com, 2005).

In 2010, the Javanese ethnic minority, H. Muhammad Sani and Soerya Respationo won the governor election (Kompas, 2010). Likewise in 2015, the Javanese ethnic candidate pair, H. Muhammad Sani and Nurdin Basirun won the governor election (Ammelia \& Kosandi, 2019, p. 143). Although it raises various perceptions from the native Malay-ethnic identity group of the non-Malay elected candidates. Most groups of the Malay community did not respond to this in a violent or repressive manner. Even the Malay people accepted the elected candidates who carry the Malay symbol in leading the Riau Islands.

Based on the background above, this research discusses primordialism and voting behavior of Malay Ethnic during the 2005-2015 Riau Islands governor election.

\section{Literature Review}

The approach in investigating voting behavior consists of three; The Columbia Study, The Michigan Model, and Rational Choice (Bartels, 2012; Roth, 2008) as cited in Haryanto (2014).

Copyright (C 2020. Owned by Author(s), published by Society. This is an open-access article under the CC-BY-NC-SA license. 


\section{Primordialism and Voting Behavior of Malay Ethnic during the 2005-2015 Riau Islands Governor Election}

These three approaches are better known as a sociological, psychological, and rational choice. This research briefly used the three approaches to better understand voter behavior.

The first is a sociological approach known as The Columbia Study pioneered by Lezarsfeild in 1940. This approach assumes those sociological values such as religion, social class, ethnicity, race, area, family traditions, and others embedded in an individual affect individual's behavior in politics (Bartels, 2012, p. 240 as cited in Haryanto, 2014). Social circles such as the family, workplace, friendship, regionalism, and so on can affect an individual's voting behavior because of social control and pressure (Roth, 2008, p. 24 as cited in Haryanto, 2014). The voting behavior in sociological perspective has the main analysis basis is social conditions, not individuals who are the center of analysis (Mujani et al., 2012 as cited in Haryanto, 2014). The sociological approach can reveal constant voter behavior due to the structural framework of each individual who only changes slowly. However, the sociological model cannot explain the causes of the shift in individual political choices.

The second approach is the Psychological Approach or what is called The Michigan Model, a choice of behavior approach that developed in the early 1950s. A complete description of the psychological approach can be found in "The American Voter" (1960) written by Angus Campbell, Philip Converse, Warren Miller, and Donald E. Stokes. Unlike the sociological model, in the psychological model, some psychological attachments/drives shape a person's political orientation. This psychological bond is caused by a feeling of closeness to the party or candidate. Individual perceptions and assessments of the candidates or the themes raised (short-term influence) greatly influence the choice of elections. In simple terms, according to Roth (2008, p. 38) as cited in Haryanto (2014), the psychological approach seeks to explain the factors that influence the decision to choose based on three attitudes: partisanship, opinion on issues, and the image of the candidate. This belief is the closest to voting decisions and therefore has a direct and very strong impact on voting behavior (Dalton, 2002, p. 173 as cited in Haryanto, 2014). Partisanship as a concept in the psychological approach is psychological closeness, which is a stable and long-lasting relationship between candidates and voters. The conditions of a candidate do self-identification as a person who mingles with the voting community as part of the group community. The identification of a candidate with the community is called a Personal ID, namely, the feeling of a candidate that regionalism is his/her political identity, that he/she does self-identification as a son of the soil in a very broad context, or that he feels one with a certain society, even though he/she is not genetically bloody the area.

The third approach is the Rational Choice model approach. Rational Choice is an approach model outside the two models of sociological and psychological approaches, which is a criticism of the two approaches. The beginning of this approach is the economic theory (Mujani et al., 2012; Bartels, 2012) as cited in Haryanto (2014). This model can be understood by economic-political analysis, where this rational voter orientation is the result achieved by certain candidates in politics. The three models of voting behavior approaches can influence each other, not necessarily contradictory. Basically, in proportionality, which actor is dominant and scientifically can explain voters' voting decisions.

Regarding the theory related to ethnic groupings, according to Mutakin (2004), groupings of Indonesian society are based on primordial ties which consist of kinship ties based on blood relations (genealogical) or descent, racial or ethnic ties, language, and religion. Therefore, according to Hapsa \& Purnomo (2016), political identity can foster inter-ethnic relations in an area so that they can have social capital, namely to occupy power. This means that political identity is not just a matter of hegemony. So in another perspective, according to Zakina (2016),

Copyright (C) 2020. Owned by Author(s), published by Society. This is an open-access article under the CC-BY-NC-SA license. 


\section{Primordialism and Voting Behavior of Malay Ethnic during the 2005-2015 Riau Islands Governor Election}

political identity in the regions affects minorities, when these minority figures can influence and even mobilize the majority group by establishing relationships with other groups.

According to Haboddin (2012), ethnicity politics is used to question between "us" and "them", "I" and "you" even to the sarcasm expression of form "Javanese" and "outside Java" or "Islam" and "Christian". This kind of oppositional dichotomy was deliberately built by local political elites to hit their enemies or political rivals, who are "immigrants". The emergence of regional movements by taking the ethnicity politics setting is part of political identity as the basis for its political movements. It has even been pointed out by many observers that the political identity movement is increasingly being used by politicians and rulers at the local level to get the cake of power, both in the political and economic fields. Therefore, according to Castells (2004), political identity is explained as identity construction, through three different angles, namely: legitimizing identity, resistance identity, and project identity. Legitimizing Identity describes the identity-building imposed by a dominant institution, for example, the State, in this case, the hegemony of state power. Meanwhile, Resistance Identity is one of the identities built with opposition to the uniformity identity carried out by the dominant institution, namely the counter identity. Resistance Identity is an understanding of the perspective of identity built from the oppressed, marginalized, or devalued by dominant group. It can be interpreted that this perspective can be easily found among minority groups and those who are marginalized, usually given to certain ethnic, racial, ethnic, or even religious groups. Project identity is an identity that is built enthusiastically by groups that uphold autonomy and want to be free from the bonds of the past (Castells, 2004).

Therefore, the attention to ethnic political identity is generally interested in studying the close relationship between ethnic groups in an area where the epicenter is the majority group. How in this case it is interesting to study because majority groups and ethnic minority groups in a country in the form of an interaction model of Ethnic political identity, namely community networks, which are based on the norms of solidarity, mutual trust, and independence of resources, are interesting things. Therefore, Mackay (2000) and Brown (2001) mention three types of ethnic identity as follows;

1) Primodialism, this perspective sees ethnic identities that are stable, fixed, ascribed, or human identity given since humans were born. This identity is attached and cannot be rejected by humans themselves, it cannot be changed in a relatively long period. The primordial approach emphasizes ethnic and religious identities which are seen as having a deep historical, genetic (native blood), and social basis so that it significantly builds the loyalty and commitment of its members.

2) Instrumentalism, a perspective that sees identity as a form of manipulation of several dominant groups. The values that exist in society such as culture, race, and religion that apply in society are used as a means of mobilization by political elites for competing for political and economic interests. An instrumental approach utilizes ethnic identity to mobilize groups to achieve political and material goals, for example, mobilizing ethnicity for control of political and economic resources. The practice of ethnic politics clearly shows how effectively this issue is used by political actors when dealing with other political entities.

3) Constructivism, which is an effort to respond to the pressure of a dominant group situation, a response to favoritism, and also to defensive efforts from a group. Based on this view, the social construction process is always associated with the involvement of group and elite community members. 


\section{Primordialism and Voting Behavior of Malay Ethnic during the 2005-2015 Riau Islands Governor Election}

Based on the explanation of the type of ethnic political identity above, there is a connection with the issues to be studied, especially how primordialism and the behavior of ethnic Malay voters in the 2005-2015 Riau Islands governor election. Where the three types are relevant above, namely Primodialism, Instrumentalism, Constructivism with Malay political identity as a model of identity political interaction, where the ability to interact with ethnic identities in politics is to establish relationships that have interdependent characteristics between ethnicities and are open or compatible in political interaction to become community identity in the struggle for regional head elections, and able to adapt to existing changes. The interaction model of political identity is expected to improve the quality of democratization in Indonesia.

This research specifically discusses how primordialism and the behavior of ethnic Malay voters in the 2005-2015 Riau Islands governor election. The results of previous studies described above found that political identity occurs in the realm of local politics; even political identity occurs and is strengthening in local politics in world countries. However, this research discusses how Malay political identity does not occur in the governor election (Pilgub) in Riau Islands. Then the object is also different from previous research. At least two previous studies were used as references, first, Aspinall (2011) in the Journal of East Asian Studies, Volume 11, Issue 2, "Democratization and Ethnic Politics in Indonesia: Nine Theses". This research used descriptive qualitative. This research examined the polarization of ethnic politics and democratization in Indonesia. After the fall of President Suharto in 1998, ethnicity has become the center of local politics in most parts of Indonesia.

Aspinall's results on the main causes of the spread of ethnic politics in Indonesia are institutional factors, the tradition of Indonesian national identity, and political architecture. Aspinall's research also found that ethnic identity in regional leader election or governor election political battles in Indonesia was used in three ways, 1) in mobilizing tribal symbols; 2) be the consideration of voters, and 3) in the selection and strategy of candidates (Sons of the soil).

Second, a research conducted by Hemay \& Munandar (2016) with the title "Politik Identitas dan Pencitraan Kandidat Gubernur terhadap Perilaku Pemilih" (Politics of Identity and Image of Governor Candidates on Voter Behavior). This research uses qualitative methods with a sociological, psychological, and rational choice explanation model. This research discusses ethnic political identity in the 2015 Bengkulu governor election. The factor of ethnic identity or ethnic sentiment, together with the image factor of figures, can positively contribute to shaping voter behavior. The results of the research showed that the ontological and sociological facts and realities state that the people's sovereignty in the regional leader election directly strengthens the flow of ethnicity in a multiethnic society which is displayed in the form of political identity. The 2010 Bengkulu governor election showed that the ethnic identity and image of the elected governor candidate constitute political identity which for voters is an important consideration in political behavior.

Based on these two previous studies, two things can be reviewed, the similarities and differences. The similarity that can be seen from the two previous studies, both the first and second reviews, is that both studies on ethnic political identity are carried out, and then discusses how ethnic identity becomes a political consideration as well as figures of running candidates who are considered worthy and have proven to contribute to the interests of society. Whereas the difference that can be taken from previous research is where the research conducted by Aspinall (2011) focused on the polarization of ethnic politics and democratization in Indonesia after the fall of President Suharto in 1998. Meanwhile, the research conducted by Hemay \& Munawar (2016) focused more on the locus of political identity and imaging politics

Copyright (C 2020. Owned by Author(s), published by Society. This is an open-access article under the CC-BY-NC-SA license. https://doi.org/10.33019/society.v8i2.207

378 


\section{Primordialism and Voting Behavior of Malay Ethnic during the 2005-2015 Riau Islands Governor Election}

in the 2015 Bengkulu governor election. Whereas this research focused more on the political factors of Malay identity that did not occur in the governor election and the factor of the winning of non-Malay candidates in the Riau Islands governor election.

\section{Research Methodology}

This research used a qualitative method with a descriptive technique. The data were collected using in-depth interviews and direct observation. Informants were selected using a purposive sampling technique. Informants in this research apart from the elites who were interviewed, but the voters were also included as a means of revealing the voting behavior, such as Malay figures, community leaders who represent the wider community in the Riau Islands. Voters' recognition (the general public in Riau Islands is the same as the opinion that was interviewed earlier) in this case, the Malay community, in principle, Malay people in Riau Islands are open and accept any ethnicity to live side by side in daily life, even if other ethnic groups are considered to have a deeper insight, they can become their leaders while waiting for their Sons of the soil to be ready to compete with outsiders.

The data collection technique was purposive sampling or non-random sampling technique where the sampling was determined the specific characteristics under the research objectives so that it is expected to answer research problems. In this qualitative research case study, the data is used to check the results surprising or unexpected. The design of this method is straightforward and easy to apply because the stages are clear and separate. Besides, this design feature makes it easy to describe and report. This research aims to describe and explain various conditions, situations, or phenomena why political identity did not happen in the Riau Islands governor election, then how are the politics of Malay identity in the context of the reality of inter-ethnic relations in the Riau Islands governor election. This research seeks to draw out the political reality of Malay identity that is open to other ethnicities that carried to develop the Riau Islands as a characteristic, character, nature, uniqueness, model, sign, or description of the conditions, situations, or phenomena of Malay identity.

In this research, data collection techniques were carried out by in-depth interviews, observation, and literature studies such as books, journals, theses, and information obtained from internet sources related to the research focus. Determination of informants was carried out by using a purposive sampling technique consisting of three registered candidates, the Malay Customary Institution (LAM), Indonesian Ulema Council (MUI), researchers, academics, the General Elections Commission (KPU), the Election Supervisory Agency (Bawaslu), Malay figures, People's Representative Council (DPR), Regional People's Representative Assembly (DPRD), and the Riau Islands government. The selection of informants was based on criteria in the following order: governor candidate and vice governor candidate were in order; Ismeth Abdullah (Governor of Riau Islands in 2005-2010), Soeryo Restipiono (Vice Governor of Riau Islands in 2010-2015), Ansar Ahmad (former Bintan Regent in 2005-2010 and 2010-2015, member of People's Representative Council in 2019-2024), Huzrin Hood (Regent of the Riau Islands in 2001-2003, Chairman of the Regional People's Representative Assembly of the Riau Islands Regency in 1999-2001, Chairman of the Executive Board for the Establishment of the Riau Islands Province (BP3KR)), Raja Malik Hafrizal (Chairman of the Indra Sakti Cultural Foundation of Penyengat Island), Datuk Abdul Razak (Chairman of the Riau Islands Province Malay Customary Institution), Musaffa Abas (Chairman of the Bintan Regency Malay Customary Institution), Razaki Persada (Head of the Riau Islands Province Election Supervisory Agency in 2012-2017), Sriwati (Member of the Riau Islands General Elections Commission in 2013-2018, Chairperson of the Riau Islands General Elections Commission in

Copyright (C) 2020. Owned by Author(s), published by Society. This is an open-access article under the CC-BY-NC-SA license. 
2018-2023), Abdul Malik (Malay Culture Researcher, Lecturer), Zamzami A Karim (Academic and Political Observer), and Ahmadi (Malay figure and Chairman of the Bintan Regency Indonesian Ulema Council).

\section{Results and Discussion}

\subsection{Governor Election (Pilgub) of Riau Islands from 2005 to 2015}

The Pilgub in the Riau Islands province has been held three times; in 2005, 2010, and 2015. In 2005, the candidate pair Ismeth Abdullah and H. Muhammad Sani won the election. This can be seen in the recapitulation results of the General Election Commission of Riau Islands Province in the 2005 Governor Election as follows:

\section{Table 2. The Recapitulation of General Election Commissions (KPU) in Governor Election of Riau Islands Province in 2005}

\begin{tabular}{|l|l|c|c|}
\hline No & Name of Candidate Pairs & Total Votes & \% Votes \\
\hline $\mathbf{1}$ & Rizal Zein and Firman Bisowarno & 27,522 & 5.40 \\
\hline $\mathbf{2}$ & Ismeth Abdullah and H. Muhammad Sani & 309,119 & 60.66 \\
\hline $\mathbf{3}$ & H. Nyat Kadir and Soeryo Respationo & 172,923 & 33.94 \\
\hline \multicolumn{2}{|c|}{ Total } & $\mathbf{5 0 9 , 5 6 4}$ & $\mathbf{1 0 0}$ \\
\hline
\end{tabular}

Source: Komisi Pemilihan Umum Provinsi Kepulauan Riau (2005)

Based on Table 2 above, it can be described in terms of the ethnicity of the 2005 Riau Islands governor election candidate pairs, namely Rizal Zein from the Malay ethnicity paired with Firman Bisowarno from the Javanese ethnicity, Ismeth Abdullah from the Sundanese-Arab ethnicity paired with H. Muhammad Sani from the Javanese ethnicity, H. Nyat Kadir from Malay ethnicity paired with Soeryo Respationo from Javanese ethnicity. In this election, the ethnic Malay were represented by H. Nyat Kadir and Rizal Zein.

Pilgub in Riau Islands Province was then held in 2010, where the winner was the candidate pair for governor and vice governor, H. Muhammad Sani and Soeryo Respationo, as shown in Table 3 below.

Table 3. The Recapitulation of General Election Commissions (KPU) in Governor Election of Riau Islands Province in 2010

\begin{tabular}{|l|l|c|c|}
\hline No & Name of Candidate Pairs & Total Votes & \% Votes \\
\hline $\mathbf{1}$ & H. Nyat Kadir and H. Zulbahri & 195,847 & 31.49 \\
\hline $\mathbf{2}$ & H. Muhammad Sani and Soeryo Respationo & 231,951 & 37.30 \\
\hline $\mathbf{3}$ & Hj. Aida Zulaikha Ismeth and Eddy Wijaya & 194,049 & 31.21 \\
\hline \multicolumn{2}{|c|}{ Total } & $\mathbf{6 2 1 , 8 4 7}$ & $\mathbf{1 0 0}$ \\
\hline
\end{tabular}

Source: Komisi Pemilihan Umum Provinsi Kepulauan Riau (2010)

Based on the ethnic distribution of the candidate pairs for governor and vice governor in the 2010 Riau Islands governor election, it can be described, namely, H. Nyat Kadir from Malay ethnicity paired with H. Zulbahri from the Minangkabau ethnicity, H. Muhammad Sani from Javanese ethnicity paired with Soeryo Respationo from Javanese ethnicity, Hj. Aida Zulaikha Ismeth from the Batak Mandailing ethnicity paired with Eddy Wijaya from the Riau Malay 


\section{Primordialism and Voting Behavior of Malay Ethnic during the 2005-2015 Riau Islands Governor Election}

ethnicity. In the 2010 governor election, the pair H. Muhammad Sani and Soeryo Respationo succeeded in becoming the winner.

Then the Riau Islands governor election was held in 2015, followed by two pairs of candidates for governor and candidates for vice governor, as shown in Table 4 below.

\section{Table 4. The Recapitulation of General Election Commissions (KPU) in Governor Election of Riau Islands Province in 2015}

\begin{tabular}{|l|l|c|c|}
\hline No & Name of Candidate Pairs & Total Votes & \% Votes \\
\hline $\mathbf{1}$ & H. Muhammad Sani and Nurdin Basirun & 347,515 & 53.20 \\
\hline $\mathbf{2}$ & Soeryo Respationo and Ansar Ahmad & 305,688 & 46.80 \\
\hline \multicolumn{2}{|c|}{ Total } & $\mathbf{6 5 3 , 2 0 3}$ & $\mathbf{1 0 0}$ \\
\hline
\end{tabular}

Source: Komisi Pemilihan Umum Provinsi Kepulauan Riau (2015)

Based on the ethnic distribution of the 2015 Riau Islands governor election, it can be described, namely, H. Muhammad Sani from Javanese ethnicity paired with Nurdin Basirun from Javanese ethnicity, Soeryo Respationo from Javanese ethnicity paired with Ansar Ahmad from Sundanese ethnicity. In this election was won by H. Muhammad Sani and Nurdin Basirun as seen in the results of the 2015 governor election recapitulation in Table 4.

From the three times the Pilgub implementation in the Riau Islands, it shows that the winning candidates are all from Javanese descent who have long lived in the Riau Islands, and have an Islamic identity, speak Malay, and have a Malay culture so that these candidates become candidates who represent Malay people. It can be understood that the winning candidates such as Ismeth Abdullah (in the 2005 governor election) and H. Muhammad Sani (in the 2010 and 2015 governor election) always appear with symbols of Malay identity (Islamic identity, Malay language, Malay culture) in the governor election battle. Besides that, the winning candidates (Ismeth Abdullah and H. Muhammad Sani) contributed a lot to the progress of the Malay community. However, candidates from the native Malay ethnicity (such as H. Nyat Kadir) did not succeed in winning the governor election. This proves that the leadership role of the candidates influences the governor's election even though the candidate who won is genetically or originally descended not from non-Malay native. However, candidates who were elected to be the Governor of the Riau Islands such as Ismeth Abdullah H. Muhammad Sani in 2005 and H. Muhammad Sani - Soeryo Respationo in 2010 and H. Muhammad Sani - Nurdin Basirun in 2015 were accepted by the Malay community and also other ethnicities in Riau Islands.

The losing of ethnic Malay candidates in the election of the governor has not been mobilized to win the sympathy of voters so that the support of Malay voters is not segmented towards Malay politicians such as H. Nyat Kadir (former Chairman of Batam Malay Customary Institution). Sometimes they asked whom should we vote for, it is very important to give a firm answer by the traditional leaders, namely the chairperson of the Malay Customary Institution for the province, regency/municipality, sub-district, and village. But in this case, there has never been a call for ethnic Malay to vote for Malay from this institution. Malay votes are given the freedom to elect not to be tied to the fatwa, appeals, and so on. So it can be understood that the mobilization of ethnic issues does not exist. This is because since the first election of governor in 2005, with the first elected governor in Riau Islands, he was not from a genealogical Malay descent, but from a Sundanese-Arab descent, namely, Ismeth Abdullah, who succeeded in building Malay with a character that mingled with the Malay community. It is as a result of

Copyright (C) 2020. Owned by Author(s), published by Society. This is an open-access article under the CC-BY-NC-SA license. https://doi.org/10.33019/society.v8i2.207

381 


\section{Primordialism and Voting Behavior of Malay Ethnic during the 2005-2015 Riau Islands Governor Election}

the open-minded characters of the Malay people. Riau Islands since the past, its history has developed the culture of Malay through non-Malay descent such as the Malay figure Raja Ali Haji who comes from Bugis descent.

\subsection{The Unhappening of Malay Political Identity during Pilgub in Riau Islands}

The results found that the politics of Malay identity did not happen in the Riau Islands governor election because first, the Riau Islands Province was formed in 2002, approximately 3 years before the first Pilgub in 2005, which was won by a candidate who was not of Malay descent, namely Ismeth Abdullah. Second, when viewed from the history of Malay, Malay figures such as Raja Ali Haji are not of native Malay descent, but Bugis descent. Third, the voting behavior of Malay people in the Riau Islands is open and the personal qualities of candidates (Personal ID) that blended with Malay culture, Malay history, and geopolitics (regional) Malay and other ethnicities in the Riau Islands. Even though these candidates are not genetically genuine or of Malay descent such as Ismeth Abdullah (Governor of the Riau Islands in 2005) and H. Muhammad Sani (Governor of the Riau Islands for the 2010 and 2015 period), all of these candidates are accepted by the Malay community as a representative of the candidates from Malay. Besides that, the ethnic Malay - Riau Islands have unique characteristics compared to ethnic Malay - Riau, Aceh, Jambi, and others.

The Identity Political Interaction Model is the ability to interact with Ethnic Identity in politics to establish relationships that are interdependent among ethnicities and are open or compatible in political interaction to become a Community Identity in the struggle for regional head elections, and able to adapt to existing changes. The Model of Identity Political Interaction is expected to improve the quality of democratization in Indonesia. Political identity in the context of theory can be understood as something alive in every ethnicity. Ethnic political identity arises when in the empirical context of political identity as a political force that dominates the participation created through community culture. One of them is Malay political identity that does not happen in the Riau Islands governor election. Where there is an understanding of political identity that does not happen in the Riau Islands governor election, so that primordialism is not properly placed in the Riau Islands governor election because candidates who come from native Malay descent, namely $\mathrm{H}$. Nyat Kadir (candidate for governor of the Riau Islands in 2005 and 2010) lost in the election competition. However, instrumentalism, where a candidate figure who could be united with a Malay identity won the governor election even though the governor elected was not genetically or of Malay descent such as Ismeth Abdullah (Governor of Riau Islands in 2005) and H. Muhammad Sani (Governor of Riau Islands in 2010 and 2015). But in fact, all the governors who are not of native descent in the land of Malay are accepted since their characteristics using a Malay identity symbol such as being identical to Islam, speaking Malay, having a Malays culture, and succeeding in building and contributing to the development in the Malay land of Riau Islands so that the Malay people chose that candidate for governor in the Riau Islands. The winning of the elected governor is not determined by the ethnic Malay identity since many other ethnicities are living in the Riau Islands, such as Javanese, Minang, Bugis, Chinese, and others. Constructivism, in the context of Malay political identity, does not happen in the Riau Islands Province. The Malay leadership, which later succeeded in identifying itself as Malay identity in Riau Islands, was supported by Javanese and other ethnicities to the candidate who had the right to lead the Malay people in a broad context.

Copyright (C) 2020. Owned by Author(s), published by Society. This is an open-access article under the CC-BY-NC-SA license. 


\subsection{The Open-Minded as Malay Ethnic Characteristics}

The acceptance of the Malay community towards Ismeth Abdullah and H. Muhammad Sani is because the winning candidates managed to establish a strong relationship with the Malay identity so that they identified themselves as Malay people by carrying symbols of Malay identities. The characteristic feature of Malay identity which is very open to other ethnicities such as Javanese, Minang, Batak, Chinese, Bugis, Flores, and others makes other ethnicities who have long lived in the Riau Islands integrate themselves as Malay people and native Malay Communities. So the native people accepted them as a large Malay family.

Malay political identity is synonymous with Islam, open-mindedness, hospitality, and human culture. Based on this instrument, the Malay identity is very open to other ethnicities. However, there is a special side of Malayness, namely a sense of belonging or a responsibility to elevate the dignity of the Malay which have a long history of Tumasik and also from the Sriwijaya kingdom, so that it seems a thick Malay political primordialism. Malays always talk about whether a regional leader should come from the Malay people. The Malay people in question are Malay in a broad sense, people who have lived for a long time in the Land of Malay and identify themselves as Malays so that they can elevate the dignity of Malay culture. So the candidate who carries the identity of Malay political primordialism in the election of the governor is considered by the Malays as a representative of the candidate for the Malays since the candidate is already united with the Malay community. This was confirmed by a candidate for vice governor in the 2015 election and two times served as Regent of Bintan, Ansar Ahmad, who said:

"I am from Sundanese descent, but I have identified myself as Malay. Malay has become one with me" (Interview, Ansar Ahmad, candidate for Vice Governor in the 2015 governor election, June 17, 2020).

In contrast to what happened to ethnic politics in Indonesia, it was very dominant, so that according to Aspinall, after the collapse of the New Order, ethnic identity in the political battles during the regional leader election in Indonesia was very strong. It is used in three ways, 1) in mobilizing tribal symbols; 2 ) be the consideration of voters, and 3) in the selection and strategy of candidates (Sons of the soil) (Aspinall, 2011). However, in contrast to the Malays in the Riau Islands, it is very different from ethnicities throughout Indonesia, there is no conflict between ethnicities and even other ethnicities fuse themselves with the Malay identity, thus affecting the political behavior of a person where they live. The spirit of "where the earth is stepped, that is where the sky is upheld" (Where we are, that is where our local customs and culture are upheld). This is evidenced by Mary R. Anderson's research; the interaction between groups is formed because a sense of community is called Community Identity, which affects a person's political behavior (Anderson, 2010). When the community identity is strengthened as according to Linda Nicholson, political identity is a political movement that arises and develops from the situation of groups that are sidelined and differentiated by the majority community of a country. The potential for the difference which is the power to carry out political movements raises communal awareness so that the difference in identity gives rise to communal awareness. As a communal force, cultural identity is effective enough to bind and integrate oneself in a community into a group construction that has the same fate and history (Nicholson, 2008). According to Raja Malik Hafrizal, Malay political identity is very open to any ethnicity due to three factors, namely the Malay culture factor, the Malay historical factor, and the geographical area factor in the Riau Islands (Interview, Raja Malik Fahrizal, Chairperson of the Indra Sakti

Copyright (C 2020. Owned by Author(s), published by Society. This is an open-access article under the CC-BY-NC-SA license. https:// doi.org/10.33019/ society.v8i2.207

383 


\section{Primordialism and Voting Behavior of Malay Ethnic during the 2005-2015 \\ Riau Islands Governor Election}

Cultural Foundation of Penyengat Island, June 14, 2020). These three factors are factors that influence the Malay values that are polite, friendly, and can metamorphose with other ethnicities.

The characteristic of open Malay identity is since Malay is not an ethnic group but rather is called a race. So the larger Malay political identity is identical to Islam. Malay is Islam, on the other hand, Islam is Malay which makes all people or the public who live in the Riau Islands who are Muslims and who have long lived in Riau Islands are called Malay people who have the right to vote (Interview, Abdul Malik, cultural researcher Malay and academics, June 15, 2020). So that is why the Malay people are not entangled with the entanglement of primordial bonds as believed by other studies. Then, the success factor of the Malay governor candidate in terms of ethnic Malay; they study the character of the Malay, for example in their daily relationships they must obey and obey the principles of existing norms. Moreover, non-ethnic Malay candidates for governor are usually more familiar among society and succeed in realizing their promises so that the community will be entrusted to lead those who the second time, then the opportunity and opportunity to be elected at a higher level will continue. For example at the national level, Ansar Ahmad has been elected as a Bintan Regent for two terms and is currently a member of the Indonesian Parliament in Jakarta.

\subsection{Candidate Figures the Easygoing of Candidates with Malay Identity and Public Opinion}

The cultural identity of Malay in the Riau Islands is strong due to the Malay people of the Riau Islands in its history is from the Tumasik and Sriwijaya kingdoms so that Malay primordialism is tied firmly. To raise the dignity, the leader should be from the Malays in a broad sense, namely, people who have lived in the Malay Land for a long time, have a Malay culture, and more importantly, they contribute to the development of the Malay land, then the leader is accepted as Malay (Interview, Ansar Ahmad, candidate for vice governor in 2015 governor election, June 17, 2020). The definition of a local man leader from Malays in a very broad context is also the same as the opinion of the key informant, the Chairman of the Executive Board for the Establishment of the Riau Islands Province (BP3KR), Huzrin Hood, who said that:

"The concept of Malay ethnic or sons of the soils of Malay area is first, the land of
Malay is open to all people, even to all immigrants. Secondly, the figures who came to
defend the Malay people. When leading, he is also good at controlling the community,
providing various facilities or projects, so that much support. In 2010, H. Muhammad
Sani (Governor of the Riau Islands for the 2010 and 2015 period), who was not a
Malay native descent as a bureaucrat, carried a Malay symbol so that he could easily
control the people. Even though they are not Malay people, they carry a Malay symbol
and respect the Malay people, that is what makes them win" (Interview, Huzrin
Hood, Chairman of BP3KR, June 12, 2020).

The open-minded characters of Malay people in the Riau Islands also influence other ethnic identity communities who strongly support the leader of the Malay region in a broad sense who can uphold the dignity of the Malay and side with the Malays, so that leaders who are "united" with the values and culture of the Malay are considered to be sons of the soil of Malay (Interview, Musaffa Abas, Figure Melayu \& Chairman of Bintan Malay Customary Institution, June 13, 2020). Malay leaders who are accepted by the Malay community are leaders who can metamorphose with Malay (Interview, Ansar Ahmad, candidate for vice governor in the 2015

Copyright (C) 2020. Owned by Author(s), published by Society. This is an open-access article under the CC-BY-NC-SA license. 
governor election, June 17, 2020). Even other ethnic groups strongly support the type of leader who carried a Malay identity and sided with the Malay, as Huzrin Hood said:

"This land is a Malay land, a Malay kingdom. But the people who live in this land are not the majority of Malay people, only about 20\%. It's also not as a determinant for winning. There are still many other ethnicities such as the Batak, Javanese, Padang, Chinese, and others, if those people respect the Malay people and the conditions of the Malay land when they appoint a leader they will side with the Malay" (Interview, Huzrin Hood, Chairman of the Executive Board for the Establishment of the Riau Islands Province, June 12, 2020).

A candidate figure that is attached to the Malay identity and has contributed and is committed to developing the Malay Riau Islands is a potential vote in the election for Governor in the Riau Islands. Besides that, the leading factor in the Malay context according to Raja Malik Hafrizal, Chairperson of the Indra Sakti Cultural Foundation of Penyengat Island, affects personal branding (self-image) in the Riau Islands governor election. According to Raja Ali Haji, there are three types of leadership concepts, namely first, the type of king's leadership as caliph, the leader brings the virtues of the Quran, and the hadiths of the Prophet Muhammad (Peace Be Upon Him) in leading the people. Second, the type of leadership of the king as a sultan, where the leader as people law enforcer. Third, the type of king's leadership is Faith, where the leader is at the forefront of fighting for the people.

The main factor of the Malay public which becomes a consideration for choosing and supporting politicians in the Riau Islands governor election is known and measured through the recognition of Malay voters and figures that the factor of the ability of figures can contribute to Malay (Interview, Raja Malik Hafrizal, Malay figure \& Chairperson of the Indra Sakti Cultural Foundation of Penyengat Island, June 14, 2020). So the argument that in the Riau Islands selling political identity is not very relevant. According to direct observation it is true that it is irrelevant because any ethnic origin as long as it has a Malay identity, it can be accepted and asked whether the contribution to the Malay people themselves if the person concerned is elected to be governor, regent or mayor. Usually, other ethnic groups can always adjust to the ethnic Malay; they make Malay as a protector of other tribes and ethnicities in the Riau Islands.

\subsection{The Proved Personal Quality of Candidates (Personal ID) as Vote Potential}

The behavior of Malay voters in Riau Islands choosing and supporting candidate " $\mathrm{A}$ " instead of candidate " $\mathrm{B}, \mathrm{C}$, or Others" is because the factor of personal quality is very important. Candidates are recognized because of their in the community (before the campaign period) to hear the aspirations of the community and offer programs needed, such as rural community program, livable house program, care programs for education, health, and other programs that make the Malay community prosperous. This can be seen from the success of the elected governor, H. Muhammad Sani, to be re-elected as governor because of his attractive work program and experience in the field of government bureaucracy.

The period of 15 years ( 3 elections for governor in the Riau Islands) shows how the voting behavior in Riau Islands is always the same and not too different in the election of candidates for governor, there has been no fatwa from local community leaders to elect candidates A, B or C. The most emphasis is on choosing a candidate for governor who can maintain the Malay entity and be able to fight for Malay. What about the split-ticket voting phenomenon that

Copyright (C 2020. Owned by Author(s), published by Society. This is an open-access article under the CC-BY-NC-SA license. 


\section{Primordialism and Voting Behavior of Malay Ethnic during the 2005-2015 \\ Riau Islands Governor Election}

occurred in the governor election in Riau Islands. Split-ticket voting is a political phenomenon where voters divide their choices among several elections, for example between legislative and governor elections. In the 2014 legislative election won by the Indonesian Democratic Party of Struggle (PDI Perjuangan), but in the 2015 governor election won by the National Democratic Party (NasDem), namely the H. Muhammad Sani - Nurdin Basirun pair defeating the pair from PDI Perjuangan, Soeryo Respationo - Ansar Ahmad. One of the reasons for the failure of the candidates nominated by PDI Perjuangan and Party of the Functional Groups (Golkar) is splitticket voting conducted by PDI Perjuangan voters. Not all Golkar voters voted for Soeryo Respationo and only a part of Golkar voters voted for Ansar Ahmad. The voter factor deliberately made split-ticket voting for a specific purpose. In the 2015 governor election, voters looked more at the programs and issues raised as well as the figurehead of a governor candidate, H. Muhammad Sani, who had proven experience in the government bureaucracy.

\subsection{Other Minority Ethnics and Political Parties Support for the Non-Malay Ethnic Candidates}

Other ethnicities outside the Malay community have a big role in winning over candidates. The candidates try to approach other ethnic identity community through ethnicity associations, such as Javanese ethnicity through Paguyuban Among Mitro, Minang ethnicity through Minang Bersatu, Batak ethnicity through Forum Batak Bersatu, Chinese ethnicity through Perhimpunan Tionghoa Kepri, and others. According to Ansar Ahmad, the candidate for vice governor in the 2015 governor election, said that other ethnicities outside of Malay have mostly identified themselves as Malays. So thus candidates who have a strong Malay color and are united with the Malay community will be supported by other ethnic identity communities such as Javanese, Minang, Sundanese, Bugis, Chinese, and others. Although culturally, Malays in the Riau Islands are dominant, all non-Malay people feel they identify themselves as Malays and other ethnicities consider Malay people in a broad context who have the right to lead the Malays in Riau Islands.

The role of political parties in the governor election in the Riau Islands is very decisive because the political parties in determining their candidates will choose the winning candidates from a certain perspective. It is necessary to deepen the survey results which are not engineering surveys, depending on the candidates. Political parties also in determining candidates pay attention to Malays requirements, which can be sold and what programs can attract the attention of the community itself. Direct observations show cartel behavior through an invisible agreement which is reflected in the decision of a political party leader to dismiss a party member nominated by another party.

\section{Conclusion}

The results found that the politics of Malay identity did not happen in the governor election due to the open voting behavior of the Malay community in Riau Islands and the personal qualities of the candidate (Personal ID) that mingled with Malay culture, Malay history, and Malay geopolitics (regional) and other ethnicities in the Riau Islands. Even though, these candidates are not genealogically or of Malay descent such as Ismeth Abdullah (Governor of the Riau Islands in 2005) and H. Muhammad Sani (Governor of the Riau Islands in the 2010 and 2015). All of these candidates are accepted by the Malay community as a representative candidate from Malay. The winning of the candidates in the governor election is determined by first, the characteristic of Malay political identity which is open-minded and carrying a symbol of Islamic identity, speaking Malay language, practicing Malay culture, and is committed to

Copyright (C) 2020. Owned by Author(s), published by Society. This is an open-access article under the CC-BY-NC-SA license. 
developing the Malay area in the Riau Islands, so candidates who have and identify themselves as Malay people are considered by the Malay community as the representative of the leader of the Malay people. Second, candidate figures who can be united (bersembati) with the Malay identity and proven successful in developing the Malay region are potential assets to gain votes. Third, candidates are supported by other ethnic identity communities such as Javanese, Minang, Batak, Sundanese, Bugis, Chinese, and others.

In the context of Malay primordialism, although the so-called Malay people narrowly have all the original (genealogical) ancestry of Malay blood, in the broader Malay context, the Malay are people who have long lived in Malay lands and are committed to developing Malays. So that in the context of instrumentalist Malay political identity, where a candidate figure who can unite (bersembati) with Malay identity won the governor election even though the elected governor is not genetically or of Malay descent, such as the elected governor is not genetically original or of Malay descent as Ismeth Abdullah (Governor of the Riau Islands in 2005 period) and H. Muhammad Sani (Governor of the Riau Islands in 2010 and 2015 period), but all governors who are not of native descent in the Malay land are accepted by the Malay community due to they acted as Malay so that the Malay people chose that candidate for governor in the Riau Islands.

So with the open-minded characteristics of the Malay identity in the Riau Islands, constructivism occurred in the context of the Malay people in the Riau Islands, which caused the Malays to choose a non-Malay candidate to become governor of the Riau Islands, who carried a Malay symbol and were committed to developing the Riau Islands region, over the governor candidates who came from original Malay descent such as H. Nyat Kadir (governor candidate in 2005 and 2010 governor election). For Malay People in the Riau Islands, the governor is not determined by ethnicity and identity but quality.

\section{Acknowledgment}

The authors would like to thank all informants who have contributed during this research, also the anonymous reviewer for critical reviews on this article.

\section{Declaration of Conflicting Interests}

The authors have declared no potential conflicts of interest concerning the research, authorship, and/or publication of this article.

\section{References}

Ammelia, E., \& Kosandi, M. (2019). Politik Kartel di Tingkat Lokal: Studi Pemilihan Wakil Gubernur Kepulauan Riau Periode Sisa 2016-2021. Indonesian Journal of Religion and Society, 1(2), 138-150. https:/ / doi.org/10.36256/ijrs.v1i2.72

Anderson, M. R. (2010). Community Identity and Political Behavior. New York, United States: Palgrave Macmillan. https:/ / doi.org/10.1057/9780230109759

Aspinall, E. (2011). Democratization and Ethnic Politics in Indonesia: Nine Theses. Journal of East Asian Studies, 11(2), 289-319. https:/ / doi.org/10.1017/s1598240800007190

Badan Pusat Statistik Provinsi Kepulauan Riau. (2015). Kepulauan Riau dalam Angka 2015. Retrieved from https:/ / kepri.bps.go.id/publication/2016/02/04/e1dbab45df325fd00fa0b1ac/kepulauanriau-dalam-angka-2015.html 
Ben-Bassat, A., \& Dahan, M. (2010). Social identity and voting behavior. Public Choice, 151(1-2), 193-214. https://doi.org/10.1007/s11127-010-9742-2

Brown, M. E. (2001). Nationalism and ethnic conflict. Cambridge, Massachusetts: MIT Press.

Buchari, S. A. (2014). Kebangkitan etnis menuju politik identitas. Jakarta: Yayasan Pustaka Obor Indonesia.

Castells, M. (2004). The network society: A cross-cultural perspective. Cheltenham: Edward Elgar Pub.

Detiknews.com. (2005, July 14). Pilkada Kepri, Calon yang Kalah Minta Diulang. Retrieved from https://news.detik.com/berita/d-403129/pilkada-kepri-calon-yang-kalah-mintadiulang

Dinas Pemerdayaan Masyarakat dan Desa, Kependudukan dan Pencatatan Sipil Provinsi Kepulauan Riau. (2019). Data Kependudukan Semester II 2019. Tanjung Pinang: Dinas Pemerdayaan Masyarakat dan Desa, Kependudukan dan Pencatatan Sipil Provinsi Kepulauan Riau.

Haboddin, M. (2012). Menguatnya Politik Identitas di Ranah Lokal. Jurnal Studi Pemerintahan, 3(1), 116-134. Retrieved from https://journal.umy.ac.id/index.php/jsp/article/view/152

Hapsa, H., \& Purnomo, E. P. (2016). Relasi Kuasa Identitas Etnis Dilembaga Legislatif Periode 2014-2019 (Studi Kasus Anggota DPRD Etnis Bugis Dikabupaten Indragiri Hilir, Provinsi Riau). Journal of Governance and Public Policy, 3(1), 124-146. https:/ / doi.org/10.18196/jgpp.2016.0053

Haryanto, H. (2014). Kebangkitan Party ID: Analisis Perilaku Memilih dalam Politik Lokal di Indonesia. Jurnal Ilmu Sosial dan Ilmu Politik, 17(3), 291-308. https:/ / doi.org/10.22146/jsp.13082

Hemay, I., \& Munandar, A. (2016). Politik Identitas dan Pencitraan Kandidat Gubernur terhadap Perilaku Pemilih. Jurnal Kajian Politik dan Masalah Pembangunan, 12(1), 1737-1748. Retrieved from http://journal.unas.ac.id/politik/article/view/163

Kaul, A. B. (2013). Ethnic Politics and Urban Voting Behavior in India: Explaining Variation in Electoral Support for the Bharatiya Janata Party, 1999-2009 (Dissertation). Department of Government and Politics, Faculty of the Graduate School of the University of Maryland. Retrieved from https:/ / drum.lib.umd.edu/handle/1903/14124

Komisi Pemilihan Umum Provinsi Riau. (2005). Rekapitulasi Perolehan Suara Pilgub Kepri Tahun 2005. Tanjung Pinang: Komisi Pemilihan Umum Provinsi Riau.

Komisi Pemilihan Umum Provinsi Riau. (2010). Rekapitulasi Perolehan Suara Pilgub Kepri Tahun 2010. Tanjung Pinang: Komisi Pemilihan Umum Provinsi Riau.

Komisi Pemilihan Umum Provinsi Riau. (2015). Rekapitulasi Perolehan Suara Pilgub Kepri Tahun 2015. Tanjung Pinang: Komisi Pemilihan Umum Provinsi Riau. Retrieved from https:/ / kepri.kpu.go.id/index.php?option=com_content\&view=article\&id=150:rekapitula si-perolehan-suara-pilgub-kepri-tahun-2015\&catid=24\&Itemid=308

Kompas.com. (2010, June 9). Sani-Soerya Menangi Pemilukada Kepri. Retrieved from https:/ / regional.kompas.com/read/2010/06/09/14221632/Sani.Soerya.Menangi.Pemilu kada.Kepri

Kristianus, K. (2016). Politik dan Strategi Budaya Etnik dalam Pilkada Serentak di Kalimantan Barat. Politik Indonesia: Indonesian Political Science Review, 1(1), 87-101. https:/ / doi.org/10.15294/jpi.v1i1.9182

Lampe, I. (2010). Identitas Etnik dalam Komunikasi Politik. Jurnal Ilmu Komunikasi, 8(3), 299-313. Retrieved from http://jurnal.upnyk.ac.id/index.php/komunikasi/article/view/133 
Mackay, B. (2000). Ethnicity. In W. Braun \& R. T. McCutcheon (Eds.), Guide to the Study of Religion. London, United Kingdom: Cassell.

Muhtadi, B. (2018). Politik Identitas dan Mitos Pemilih Rasional. Maarif, 13(2), 68-86. Retrieved from http:/ /jurnal-maarifinstitute.org/index.php/maarif/article/view/23

Mutakin, A. (2004). Dinamika Masyarakat Indonesia. Bandung: PT. Ganesindo.

Nasution, I. K. (2014). Ethnicity, Democracy and Decentralization: Explaining the Ethnic Political Participation of Direct Election in Medan 2010. Procedia Environmental Sciences, 20, 496-505. https:// doi.org/10.1016/j.proenv.2014.03.062

Nicholson, L. (2008). Identity before Political Identity. Cambridge, United Kingdom: Cambridge University Press.

Nordholt, H. S. (2008). Identity Politics, Citizenship and the Soft State in Indonesia: an Essay. Journal of Indonesian Social Sciences and Humanities, 1(1). https:/ / doi.org/10.14203/jissh.v1i1.1

Trihartono, A., \& Patriadi, H. B. (2016). The 2014 Indonesian general election and beyond. Asian Journal of Comparative Politics, 1(1), 25-43. https:/ / doi.org/10.1177/2057891115620699

Zakina, N. F. N. (2016). Politik Etnisitas dan Compliance Gaining Kandidat Minoritas dalam Pilkada Kalimantan Barat. Jurnal Komunikasi Ikatan Sarjana Komunikasi Indonesia, 1(2), $122-$ 129. https://doi.org/10.25008/jkiski.v1i2.58

\section{About the Authors}

1. Kustiawan, obtained his Magister degree in Political Science from Kokushikan University, Japan, in 2008. The author is an Assistant Professor at the Department of Government Science, Faculty of Social and Political Sciences, Universitas Maritim Raja Ali Haji, Indonesia.

E-Mail: kustiawan@umrah.ac.id

2. Rumzi Samin, obtained his Doctoral degree from Universitas Pasundan, Bandung, Indonesia, in 2012. The author is an Associate Professor at the Department of State Administration, Faculty of Social and Political Sciences, Universitas Maritim Raja Ali Haji, Indonesia.

E-Mail: rumzisamin@umrah.ac.id 